\title{
Background information on Faure Island, Shark Bay, Western Australia
}

\author{
Barry Wilson \\ 4 St lves Loop, Kallaroo WA 6025, Australia; E-mail: murexustarwon.com.au
}

\begin{abstract}
Background information is given on a biological survey of Faure Island, Shark Bay, conducted to provide a basis for a translocation program involving threatened mammal species presently surviving on outer islands of the bay. Tenure, climate, geology and land forms of the island are summarised. Late Pleistocene marine shell beds are described that represent transgressive phases of the last interglacial. Above these are dune deposits containing fossil land snails deposited during the arid, low sea level period of the last glacial cycle prior to the post-glacial transgression that re-created the bay and isolated Faure as an island. This geomorphic history is discussed in relation to the extinction of the mammal species on the mainland of the region and the suitability of Faure Island as a translocation site.
\end{abstract}

Key words: Shark Bay World Heritage Property, tenure, climate, geology, land forms, threatened mammals, shell beds, transgression, translocation

\section{INTRODUCTION}

Faure Island is a small pastoral lease, of 5,816 ha, in the Shire of Shark Bay, located within the Shark Bay World Heritage Property. It was purchased by the Australian Wildlife Conservancy (AWC; then Paruna Sanctuary Ltd.) in 2000 for conservation and education. In particular, it was obtained as a site for the translocation and establishment of secure populations of threatened species of native mammals.

As an island of modest size, Faure has special conservation values. It offers suitable habitat for several of the native mammals once abundant in the region but now extinct on the mainland. It is large enough to offer sufficient area to support viable wild populations of the selected species without intrusive management. It is small enough for habitat restoration and population monitoring to be manageable. And, as an island, it is moderately secure from invasion of the exotic predators and herbivorous competitors that are believed to have been responsible, at least in part, for the extinction of the selected species on the adjacent mainland.

The AWC principal management objectives for the island were:

- restoration and protection of natural habitats and wildlife, principally through de-stocking (sheep, goats and horses) and eradication of exotic predators (cats);

- reintroduction of threatened mammals native to the region and the establishment of secure populations of the selected species that may become a supplementary source of stock for translocations to the mainland;

- research on the life histories and ecology of the selected species that may inform conservation programs elsewhere; and

- development of education and training programs that enhance understanding of the natural history and major conservation issues of the region.

Although there has been intensive study of the flora and fauna of the Shark Bay region, both marine and terrestrial, Faure Island has been largely overlooked until now. There had been brief earlier visits by biologists but no comprehensive flora and fauna survey had been done. The only habitat information available had been the general classification of land systems of the island relating to the nature and condition of its pasture. This did not provide a sound basis upon which a threatened species translocation program could be planned and implemented.

Accordingly, AWC arranged a biological survey of Faure Island between 22 May - 2 June 2000, conducted by experts with a range of natural history expertise. The general aim of the survey was to assess the current and recent habitats and species diversity of native plants and animals on Faure Island as a basis for the development of a management plan.

This publication reports the results of the 2000 survey, supplemented by some information from earlier visits and some obtained by AWC staff during subsequent work on the island. The section on the geology of the island has drawn on information in an unpublished, preliminary field report by Dr Philip Playford and Dr Patrick Berry to the AWC (Playford and Berry 2002). The report also includes the results of a surver of the 
abundance of feral cats on Faure Island prior to the implementation of an eradication program that followed after the 2000 survey was completed.

At the time this report was assembled for publication (July 2007) all but one of the horses had been removed from the island, sheep had either been removed or restricted to a single paddock, and feral goats (remnant from earlier pastoral practices) and cats had been successively eradicated. With that basis, and with the benefit of the habitat information provided by the survey, a mammal translocation program had been initiated (Burrowing Bettong Bettongia lesueur, Shark Bay Mouse Pseudomys fieldi, Banded Hare-wallaby Lagostrophus fasciatus, Western Barred Bandicoot Perameles bougainville, Greater Stick-nest Rat Leporillus conditor; Richards 2007). The progress of the translocation programs will be reported elsewhere.

\section{SURVEY PARTICIPANTS}

\section{Australian Wildlife Conservancy}

$\begin{array}{ll}\text { Martin Copley } & \text { Founder and Chairman } \\ \text { Barry Wilson } & \text { Director, zoologist } \\ \text { Tim Flannery } & \text { Director, zoologist } \\ \text { Andre Schmitz } & \text { Sanctuaries Manager, zoologist } \\ \text { Leon Pericles } & \text { Artist } \\ \text { Daniel Bowles } & \text { Assistant } \\ \text { Dick Hoult (sen.) } & \text { Assistant } \\ \text { Richard Hoult } & \text { Assistant } \\ \text { Elvie } & \text { Cook }\end{array}$

Western Australian Department of Environment and Conservation

Greg Keighery Botanist

Western Australian Museum

$\begin{array}{ll}\text { Patrick Berry } & \text { Marine zoologist } \\ \text { Alexander Baynes } & \text { Mammalogist } \\ \text { Julianne Waldock } & \text { Invertebrate zoologist } \\ \text { John Dell } & \text { Ornithologist }\end{array}$

\section{South Australian Museum}

Steve Donnellan Vertebrate zoologist

Terry Reardon Mammalogist

Jan Forrest Invertebrate zoologist

\section{COLLECTION AND LODGEMENT OF SPECIMENS}

For the most part, protected species were identified and recorded in the field without the need for collection of specimens. Where voucher specimens were taken for further study, this was done under licence issued by the Western Australian Department of Conservation and Land Management (now Department of Environment and Conservation; DEC), with the vertebrate and invertebrate specimens lodged in the collections of either the Western Australian Museum or the South Australian Museum. Plant specimens were lodged at the Western Australian Herbarium.

\section{LOCATION AND TENURE}

Faure Island is located in Disappointment Reach, the eastern gulf of Shark Bay (Figure 1). It is centred on $25^{\circ} 50^{\prime} \mathrm{S}, 113^{\circ} 53^{\prime} \mathrm{E}$ and lies within the Shark Bay World Heritage Property.

The island is Crown Land, comprising a pastoral lease, a narrow coastal reserve on the eastern side and a narrow strip of Unassigned Crown Land (UCL) on the western side. It is entirely surrounded by the Shark Bay Marine Park (Reserve 7).

The eastern reserve (Crown Reserve 30885) is vested with the Conservation Commission (DEC) with the $40 \mathrm{~m}$ strip above High Tide Level reserved for "Preservation of Sedimentary Deposits". The corresponding $40 \mathrm{~m}$ strip of UCL along the western side is intended for reservation in the near future as part of the Marine Park.

The pastoral lease has an area of 5,816 ha comprising the whole of that part of the island enclosed within the boundary set at $40 \mathrm{~m}$ above the high water mark. The lease is numbered 3114/922, issued to the Australian Wildlife Conservancy (AWC) by the Pastoral Lands Board (PLB) under the authority of the Land Administration Act 1997. The lease expires in the year 2015 but will be renewed beyond that date subject to certain conditions.

The Shark Bay Regional Strategy (Western Australian Planning Commission 1997) indicates that Faure Island should remain under pastoral tenure. Management of the pastoral lease by AWC will include operations to promote conservation of the island's natural environment and wildlife under a Division 5 permit.

Under the provisions of the World Heritage Properties Conservation Act 1983, Shark Bay was entered on the World Heritage List in 1991 following nomination by the Australian Government with the agreement of the Western Australian Government. The Shark Bay World Heritage Property encompasses Faure Island. The nomination document identifies scenic qualities that include those of Faure Island, and key seabird breeding sites on the island as among the World Heritage values. Management of Faure Island will take World Heritage status and the specified universal values into account.

The Shark Bay Marine Park, established under the Conservation and Land Management Act in 1990, surrounds Faure Island and extends up to the high tide mark. The plan designates the waters around Faure Island as a General Purpose Zone. 


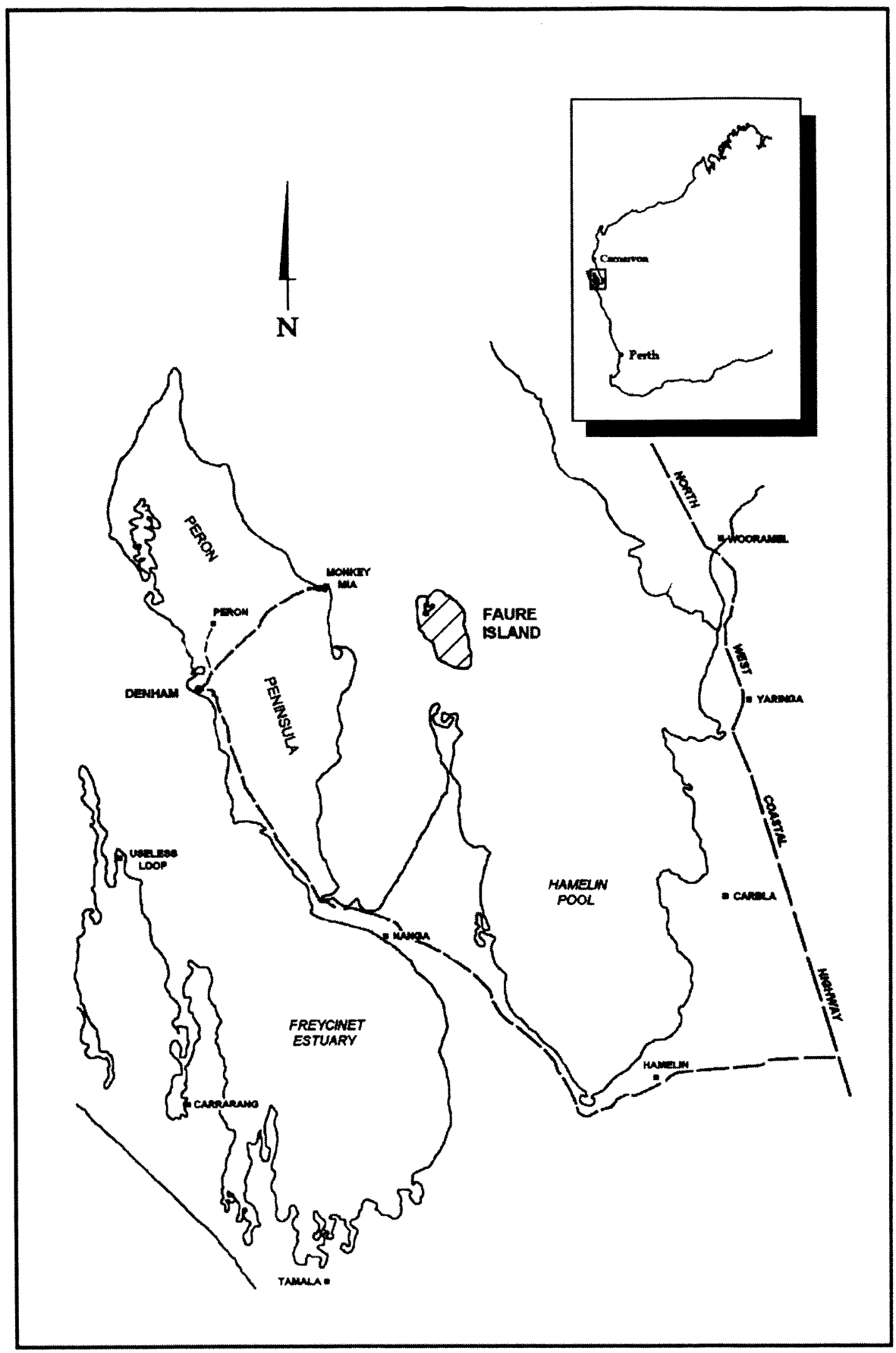

Figure 1 l.ocation of Faure Island in Shark Bay, Western Australia.

\section{CLIMATE}

Shark Bay has a semi-arid to arid climate with hot dry summers and mild winters. Summer minimum and maximum temperatures average between about $20^{\circ}$ and $35^{\circ} \mathrm{C}$ respectively and winter temperatures between about $10^{\circ}$ and $20^{\circ} \mathrm{C}$. Rainfall is erratic with annual totals ranging from 200 to $400 \mathrm{~mm}$ at the Denham weather station. Most rain falls in the winter months but cyclones bring summer rain in some years. Faure Station records collected between 
1991 and 2005 show that rainfall on the island falls predominantly between March and August with an average of $185 \mathrm{~mm}$ per annum (AWC, unpublished data).

Annual evaporation rates within the area are very high ranging from 2000 to $3000 \mathrm{~mm}$. Rainfall is greater and evaporation rates lower on the western side of Shark Bay than on the eastern side (including Faure Island), which tends to be more arid.

In summer winds are predominantly southerly and may blow for long periods at over $25 \mathrm{~km}$ per hour. Winds tend to be lighter in winter although low pressure system winter storms occur occasionally. Faure Island is protected from severe westerly and southerly storms by the mainland but is exposed to heavy weather from the north early in the life of both summer cyclones and winter storms.

\section{GEOLOGY}

Shark Bay lies within the Carnarvon Basin. The surface geology consists of Pleistocene and Holocene limestone and sandstone, overlaying the Late Cretaceous Toolonga Calcarenite (Hocking et al. 1987) and largely covered by superficial sand (Playford 1990).

Faure Island is built of Peron Sandstone, a Pleistocene unit of soft, poorly consolidated, orange-red, eolian sandstone which formed as dune systems over anticlinal ridges developed in the underlying formations. The Peron Sandstone is exposed around much of the periphery of the island, forming "rocky" headlands where it is eroded by the sea and scree slopes where it is exposed below calcrete-topped cliffs. It gives rise to the orange-red sand that forms the contemporary dunes covering much of the surface of the island. In stark colour contrast, in many places there are coastal foredunes and plains comprising white Holocene sand derived from the contemporary intertidal flats that surround the island.

An undulating subsurface layer of calcrete formed within the Peron Sandstone below the present land surface. It is exposed at several localities, including surface outcrops in low swales in the centre of the island and as hard crusts on cliff tops producing breakaway topography along both the west and east coasts. On the west coast there are also blown out dunes where the calcrete surface is exposed.

There are two units of Late Pleistocene marine limestones outcropping around the shores of Shark Bay (Logan et al. 1970; Hocking et al. 1987; Kendrick 1990; Playford 1990) including Faure Island. They are thought to represent transgressive marine episodes of the last interglacial in the Late Pleistocene, the former relating to substage $5 \mathrm{e}$ (Shackelton and Opdyke 1973) and the latter possibly to a subsequent transgressive period (Kendrick 1990).
The older of these two marine deposits, the Dampier Limestone, contains a rich fauna of intertidal marine molluscs broadly like the fauna of contemporary sandflats in Shark Bay but including several species not now living in the region (Kendrick 1990). For example, the cardiid bivalves Acrosterigma dupuchense and Fragum carinatum are very common in these fossil deposits but their living Australian distributions are now confined to the Pilbara and Kimberley coasts north-east of North West Cape. Also present among these fossils is the arcid bivalve Anadara trapezia, which is characteristic of hyposaline estuarine environments and is thought to indicate a period of relatively moist climate and possibly associated with the Wooramel River when the river flowed more strongly (Kendrick 1990; Kendrick et al. 1991; Murray-Wallace et al. 2000). This species also became extinct on the west coast after the last interglacial.

At Faure Island there are Late Pleistocene shell deposits that are of clearly two different facies representing very different depositional environments. They may represent the Dampier and Bibra Limestones but their relationship is not clear and requires detailed study.

In the north of the island, along the southern shore of an ephemeral salt lake opening into the eastern side of Tadpole Lagoon (Figure 2), there is an exposure of limestone at water level containing fossil bivalves in a fairly well consolidated matrix. A hand-held GPS unit gave an elevation at the top of this exposure of about three metres above mean sea level. The bivalves include both Acrosterigma dupuchense and Anadara trapezia and it seems likely that this is an exposure of the Dampier Limestone. The presence of Anadara trapezia suggests deposition in an estuarine environment (see above).

Adjacent to this exposure, and apparently overlying it, there is a shell bed of a very different facies. It occurs at the break of slope between the surrounding dunes and the water level of the salt lake and extends around the southern shore of the lake and lagoon for a distance of several hundred metres. This deposit, $1-1.5 \mathrm{~m}$ thick, is not consolidated but comprises a rich assemblage of bivalves (many of them articulated) and some gastropods in a loose matrix of quartz sand. The top of this deposit is not level and GPS readings gave elevations ranging from 5-9 $\mathrm{m}$ above mean sea level. Acrosterigma dupuchense is common among the many species of bivalves present but Anadara trapezia is not. The facies and molluscan assemblage appear to represent a marine intertidal sand flat that was not estuarine, while the presence of Acrosterigma dupuchense indicates that it is of Late Pleistocene age and not Holocene. The contact between this deposit and the slightly lower one has 


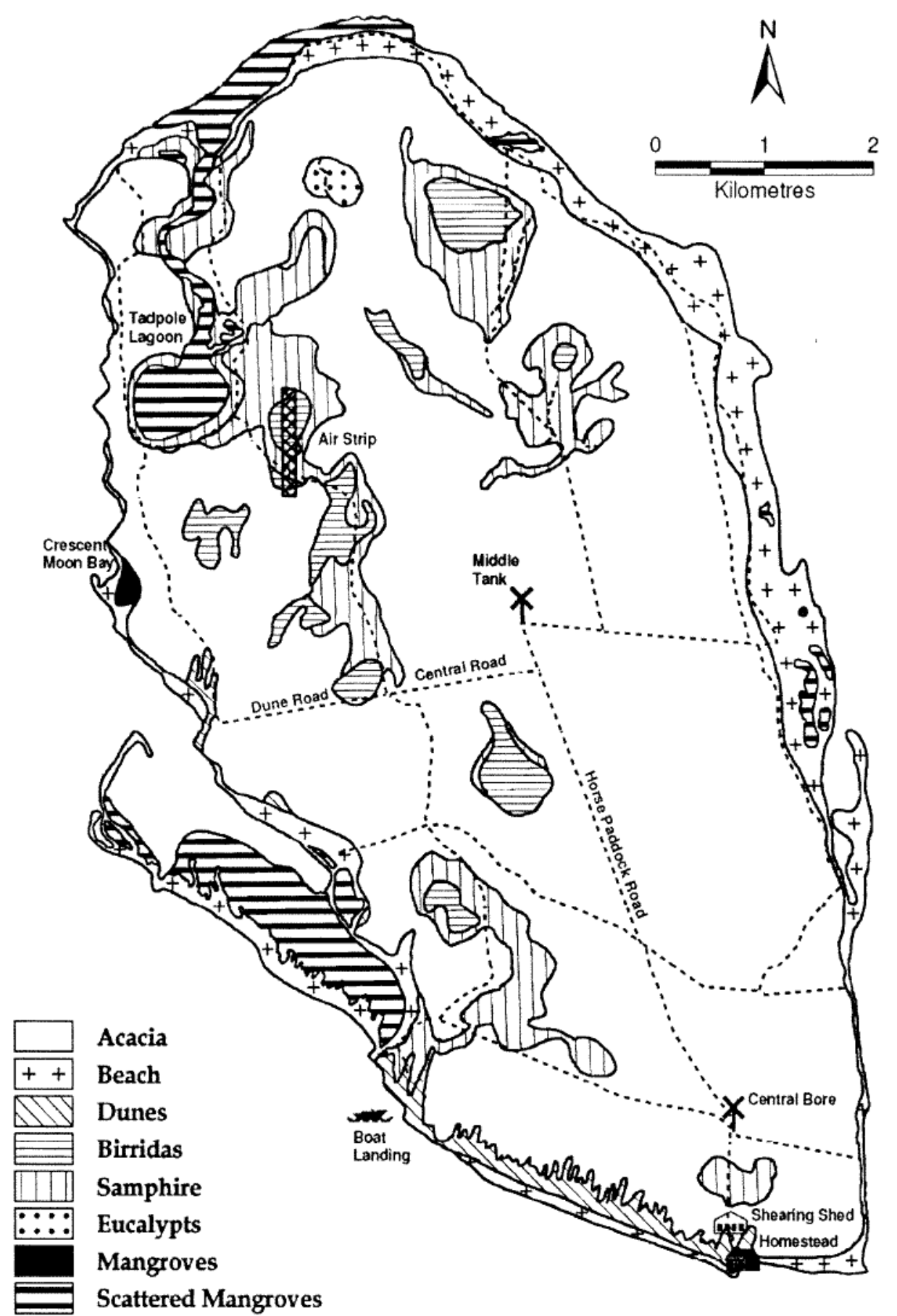

Figure 2 Vegetation of Faure lsland.

not been observed but it seems reasonable to interpret the higher shell bed as the result of a later transgressive event, possibly equivalent to the Bibra limestone that occurred after the termination of estuarine conditions.

At the southern end of the island, in the vicinity of the boat landing site, there is a conspicuous shell deposit with a facies and molluscan assemblage very similar to the higher one at Tadpole Lagoon. It is eroded by the sea and forms a low, undercut bench along several hundred metres of the shore. The top of this shell bed has an undulating surface but is generally $1-2 \mathrm{~m}$ above high tide level. It lenses out at the eastern and western ends but at the centre it is about $1.5 \mathrm{~m}$ thick. Below it is poorly consolidated orange-red quartz sand. Above it is a thickness of poorly consolidated orange-red Pleistocene sand forming the coastal dunes of that part of the island. Like the higher deposit at Tadpole Lagoon, Acrosterigma dupuchense and Fragum carinatum are common among the many species of bivalves present but Anadara trapezia is not. However, two very worn valves of the latter species were picked up at the water's edge in the vicinity. They do not appear to have come from the supra-tidal shell bed. Further searches may reveal 
an exposure of Dampier Limestone in the intertidal zone below the supratidal shell bed.

The semi-consolidated dunes above the southern shell bed are eroding rapidly, forming an irregular shore "cliff" with blown out dunes above. Embedded within these sands are fossils of the land snail Bothriembryon onslowi. Specimens may be observed embedded in the exposed face of the cliff within centimeters of the top of the underlying marine shell bed. These deposits may be interpreted as representing a terrestrial depositional phase immediately following the final Late Pleistocene sea regression. It is noteworthy that a sample of these fossil snails were significantly larger than their descendants living on the island at the present time (Wilson 2008). It is suggested that this species may have existed continuously in that area throughout the terrestrial period of the last Pleistocene glacial until the present but became smaller.

\section{LAND FORMS}

There are three distinct landform types in Shark Bay. Faure Island belongs to the Peron Province which comprises undulating sandy plains and dunes with interdunal birridas. The Peron Province includes two of the peninsula-island ridges that contain and divide Shark Bay, that is, the Nanga/ Peron Peninsula unit and the Petit Point/Faure Island unit. Faure Island represents a seaward extension of the latter.

In a 1986 submission to the Shark Bay Regional Plan the Western Australian Department of Agriculture (AgWest) referred to the Peron landform as the Victoria Sand Plain geomorphic region and described it as an "extensive flat to undulating plain of sand". Within this geomorphic region AgWest identified several land systems, three of them represented on Faure Island - Birrida, Littoral and Sandplain (Figure 2; Keighery and Muir 2008).

The Faure Sill, a bank of Holocene sand forming vast areas of sandy shallows, crosses the eastern gulf of Shark Bay (Disappointment Reach) from the Peron Peninsula to the mainland on the eastern shore. Apart from a series of deep channels it bars the mouths of Hamelin Pool and Lharidon Bight. Faure Island is an emergent portion of the Sill and is entirely surrounded by sandy flats, much of which are exposed during periods of low spring tide.

The general topography of the island comprises two roughly north-south dune ridges forming the western and eastern margins of the island with lower dunes and swales in between. The highest point on the island is a dune on the north eastern side whose summit is $26 \mathrm{~m}$ above sea level.

During the Holocene the seaward sides of the dune ridges of Faure Island were severely eroded by the sea following the last post-glacial rise of sea level, forming steeply sloping, breakaway cliffs with calcrete rims, especially along the western and eastern shores. The process of erosion and shore regression is continuing on the western shore, the loose sand from the cliff faces slipping down to the shore and being spread by wave action across the flats. There is evidence that the western shore may have been subject to Late Pleistocene or Holocene uplifting (Playford and Berry 2002). But along the northern, southern and eastern sides of the island the shore is prograding with accumulation of white Holocene sand to form sandy beaches, narrow coastal plains and foredune systems.

Along the western and southern shores there are several blow-outs in both the orange-red Pleistocene and white Holocene dunes. In the case of the Pleistocene dunes the sand above the calcrete layer has blown off, accumulating as mobile dunes behind the cliffs. The calcrete surface is exposed in such places. In situ it has an undulating surface with laminated convex structures that, when exposed, appear as dome-shaped protrusions, creating a very unusual landscape. Fossil bones of cormorants have been found in one such blow-out, interpreted by Playford and Berry (2002) as evidence that the site may once have been a cormorant rookery like the contemporary ones at the northern end of the island.

Playa lakes, known locally as birridas, occur in the interdunal swales and contain evaporite deposits consisting largely of gypsum, believed to be of Pleistocene age.

In three areas, the southwestern corner, the northwestern corner and the eastern side, tidal flows and wind driven waves have formed series of chernier sand spits enclosing shallow lagoons that support mangrove vegetation (mangals) and associated supra-tidal samphire flats.

\section{SHORE HABITATS}

Faure Island is located within the Faure Salinocline of the eastern gulf (Logan and Cebulski 1970). It is within that part of the gulf where there is rapid change from the metahaline condition of the northern part of the gulf, to the hypersaline water masses of semi-enclosed Lharidon Bight and Hamelin Pool in the south. The range of salinity is likely to be much lower at the southern end of the island than at the northern end, with corresponding change in marine communities.

The three most important shore habitats around Faure Island are i) intertidal flats, ii) shallow lagoons and iii) mangals. At some locations on the western side of the island there are "rocky" shores, composed of semi-consolidated Peron Sandstone. However, these rocks are soft and friable and do not provide suitable habitats for rocky shore communities. 


\section{Sand flats}

The island is surrounded by wide intertidal sand flats and the shore comprises mostly sandy beaches, with either reworked sands derived from the Pleistocene Peron Sandstone or Holocene marine carbonate sands derived from the contemporary flats. At low spring-tide the flats are exposed. Beyond low spring-tide level, the sand flat habitat passes to dense seagrass beds which form one of the dominant marine habitats in Shark Bay (Walker 1990).

The sand flats support a very rich burrowing invertebrate fauna, especially small polychaetes and bivalved molluscs (Slack-Smith 1990). The biomass of these organisms provides a food resource for large numbers of shore birds. The flats on the eastern end of the island are more muddy than on the windward eastern side and appear to have an exceptionally rich biomass. It is this habitat that supports extremely large numbers of shore birds through the summer months.

\section{Shallow lagoons}

At the south western corner and along the eastern side of the island, tidal flows and wind driven waves have formed chernier sand spits enclosing shallow lagoons that are open to the north. The lagoons are fringed with mangroves and associated supratidal mud flats vegetated with halophytic succulent shrubs.

The largest and deepest of the lagoons is located at the southwest corner of the island. It has a depth of more than one metre and is used as a safe anchorage for small vessels.

At several locations on the east coast, series of sand spits of different age have produced lagoons at different stages of development. The older ones closest to shore are filled with sediment and are inundated only by extreme high tides. The younger ones (seaward) retain water even at low tide. They are developing mangals and are in early stages of siltation. In this way the east coast is prograding.

At the northern end of the island the sea has flooded via a narrow, shallow channel, into a meandering, multi-lobed birrida forming an inland lake. It was dubbed 'Tadpole Lagoon' by survey participants because of its shape.

The shallow lagoons appear to be places of exceptionally high primary production and play a significant role in the ecology of the surrounding shallows. A large Pied Cormorant rookery in mangrove trees at or near the entrance of Tadpole Lagoon is particularly interesting in this regard (Dell and Cherriman 2008). The shallow channels and tidal pools in that area are nutrified during the cormorant breeding season. Mangrove trees are seriously damaged by the birds and their excrement while they are breeding, but regrowth of young mangroves at these places during the following year is particularly vigorous.

\section{Mangroves}

Shark Bay is the most southerly area where complex mangrove (mangal) systems occur on the west coast (Johnstone 1990). Within the bay the most dense and structurally developed mangals occur at Guichenault Point on the eastern side of Peron Peninsula, the mainland coast on the eastern side of the eastern gulf, and on the shores of Faure Island.

The largest of the Faure mangals is in the wide lagoon at the windward south-western corner of the island. Lesser examples occur as fringes along the channels of Tadpole Lagoon and the muddy northern shore and in the lagoons on the eastern side of the island.

On the tropical Pilbara and Kimberley coasts, mangals comprise many kinds of mangrove tree and have a species-rich associated fauna of molluscs, crustaceans and other invertebrates. The Faure Island mangals comprise a single mangrove species, Avicennia marina, with a zone of succulent shrublands around their shoreward margins which are inundated at high tide (Keighery and Muir 2008). They support a restricted fauna, with very poor representation of the suite of obligate mangrove associates that are characteristic of this habitat further north. This is a manifestation of the north-south attenuation in tropical marine plant and animal species on the west coast (Wilson and Allen 1987).

No study of the Faure Island mangrove fauna has been attempted but it seems that only two of the mollusc species characteristic of this habitat in northern Western Australia occur on the island. The potamidid mud-creeper Terebralia semistriatus lives in dense colonies on the mud flats in and around the mangrove trees. The littorinid Littoraria cingulata (endemic Shark Bay subspecies L. c. pristissini) lives on the mangrove trunks and in vast numbers in the adjacent zone of succulent shrubs. There is only one species of fiddler crab, $U_{c a}$ elegans, which lives in colonies in burrows on mud flats high in the intertidal zone behind the mangrove trees. There is only one other conspicuous crab in the mangals, Neosarmatium trispinosum, which lives in turreted burrows among the pneumatophores of the mangroves and the stems of the succulent shrub Halosarcia indica.

\section{LATE PLEISTOCENE-HOLOCENE HISTORY OF FAURE AND ITS RELEVANCE TO THE TRANSLOCATION PROJECT}

Shark Bay has had a very unstable history through the Quaternary as a consequence of change in both climate and sea level. Throughout this period sea level fluctuated significantly.

A major transgressive, warming event initiated the last interglacial phase of the Late Pleistocene 
about 128,000 years ago. Sea level rose to a few metres above that of the present time and oscillated around that level for several thousand years [corresponding to substage $5 \mathrm{e}$ of the deep-sea isotopic chronology of Shackelton and Opdyke (1973)]. Shark Bay was formed at this time. Faure Island may then have existed as an island but more likely as a set of sandy cays with some emergent parts. This period is recorded in the sediments of the island by the Late Pleistocene shell beds described above. There is evidence that during this time the climate was wetter than it is at present (Wyroll 1993).

Around 115,000 years ago a period of global cooling began and sea level fell dramatically, fluctuating between about $20 \mathrm{~m}$ and $130 \mathrm{~m}$ below its present level until about 18,000 years ago. This is the normal state of the region with the continental shelf much narrower than it is today. During this relatively long period, the broad gulfs of Shark Bay did not exist and sand dunes accumulated on top of the Late Pleistocene marine deposits. Faure Island was not then an island but a series of dunes on a sandy plain. Terrestrial plants and animals colonised the new dunes, including the snail Bothriembryon onslowi whose fossil remains may be found in the semi-consolidated sand immediately above the marine deposits (see above and Wilson 2008).

At around 18,000 years ago, global cooling peaked and the sea suddenly fell to at least $130 \mathrm{~m}$ below its present level. This was a time of greater aridity and cooler conditions (Kendrick 1978; Wyroll 1993). In the latitude of the present Shark Bay, the shore was then located west of the line from Cape Farquar to Point Quobba and thence down the western sides of Bernier, Dorre and Dirk Hartog Islands. The dunes of Faure Island were merely high points on the Petit Point/Faure dunal ridge nearly $100 \mathrm{~km}$ from the sea.

Sea level rose abruptly during the Flandrian Transgression immediately after the glacial maximum 18,000 years ago, reaching its present level about 6,000 years ago and creating Shark Bay. What had been high parts of the coastal plain became peninsulas such as Peron and Petit Point, or islands such as Faure, surrounded by the shallow waters of the bay. The contemporary peninsula and island floras and faunas are relics of those that had persisted on the coastal plain through the arid Late Pleistocene and survived the subsequent warming event.

Isolation on islands may have significant consequences on flora and fauna. Reduced area and isolation from other breeding populations, coupled with climatic change, increase the risk of local extinction in some species. Conversely, isolation on islands may bring protection from threatening processes such as predation and fire that prevail regionally. The survival of certain native mammals on the outer islands (Bernier and Dorre Islands) of Shark Bay, and their extinction on the mainland is an example.

In the present context, that is, management of Faure Island as a wildlife sanctuary and a site for the reintroduction of threatened mammals, this is an important consideration. We need to consider the possibility that native species that colonised these arid sand plains after retreat of the sea 110,000 years or so ago may have faced local extinction. pressure when the sea rose again, the area of terrestrial habitat became drastically reduced and the island populations became isolated from mainland populations.

Baynes (2008) has shown that several native mammals once present on the island are now extinct there. Whether they became extinct because of climate change, isolation and reduced habitat, that is, from "natural causes", is a key question in relation to the AWC translocation project. In the absence of information that these animals were extant on the island until the time of human occupation, it cannot be assumed that the extinctions are a consequence of goat and sheep grazing or cat predation brought by humans in the $19^{\text {th }}$ and $20^{\text {th }}$ centuries. Nevertheless, while grazing and feral predation may not be the cause of extinction, they would surely be unhelpful to a reintroduction program in circumstances where there are natural stresses. Eradication of feral cats (Algar and Angus 2008) and removal of sheep and goats is critical to the success of the reintroduction project.

\section{ACKNOWLEDGEMENTS}

The author thanks all the members of the survey team for their assistance in the field and their lively contributions to discussions of the objectives and results. Dr Philip Playford and Dr Patrick Berry made helpful suggestions in regard to the section on geology. Most of all, the author acknowledges the input of AWC founder and Chairman, Martin Copley, whose enthusiasm and support were fundamental to the success of the project.

\section{REFERENCES}

Algar, D. and Angus, G.J. (2008). Feasibility study for the eradication of feral cats from Faure Island, Shark Bay, Western Australia. Records of the Western Australian Museum Supplement 75: 71-75.

Baynes, A. (2008). The original non-volant mammal fauna of Faure Island, Shark Bay, Western Australia. Records of the Western Australian Museum Supplement 75: 25-31.

Dell, J. and Cherriman, S. (2008). The birds of Faure Island, Shark Bay, Western Australia. Records of 
the Western Australian Museum Supplement 75: $55-70$.

Hocking, R.M., Williams, S.J., Moor, H.T. and Van De Graff, W.J.E. (1987). Geology of the Carnarvon Basin, Western Australia. Western Australia Geological Survey Bulletin 133: 289 pp.

Johnstone, R.E. (1990). Mangroves and Mangrove Birds of Western Australia. Records of the Western Australian Museum Supplement 32: 120 pp.

Keighery, G. and Muir, W. (2008). Vegetation and vascular flora of Faure Island, Shark Bay, Western Australia. Records of the Western Australian Museum Supplement 75: 11-19.

Kendrick, G.W. (1978). New species of fossil nonmarine molluscs from Western Australia and evidence of late Quaternary climate change in the Shark Bay district. Royal Society of Western Australia 60: 49-60.

Kendrick, G.W. (1990). A Pleistocene molluscan fauna with Anadara trapezia (Deshayes) (Bivalvia: Arcoida) from the Dampier Limestone of Shark Bay, Western Australia (pp. 33-48). In: Berry, P.F., Bradshaw, S.D. and Wilson, B.R. (eds), Research in Shark Bay, Report of the France-Australe Bicentenary Expedition Committee. Western Australian Museum, Perth, WA.

Kendrick, G.W., Wyroll, K-H. and Szabo, B.J. (1991). Pliocene-Pleistocene coastal events and history along the western margin of Australia. Quaternary Science Reviews 10: 419-439.

Logan, B.W., Read, J.F. and Davies, G.R. (1970). History of carbonate sedimentation, Quaternary Epoch, Shark Bay, Western Australia. In: Carbonate sedimentation and environments, Shark Bay, Western Australia. American Association of Petroleum Geologists Memoir 13: 38-84.

Logan, B.W. and Cebulski, D.E. (1970). Sedimentary environments of Shark Bay, Western Australia. In: Carbonate sedimentation and environments, Shark Bay, Western Australia. American Association of Petroleum Geologists Memoir 13: 1-37.

Murray-Wallace, C.V., Beu, A.G., Kendrick, G.W., Brown, L.J., Belpirio, A.P. and Sherwood, J.E. (2000). Palaeoclimate implications of the occurrence of the arcoid bivalve Anadara trapezia (Deshayes) in the Quaternary of Australasia. Quaternary Science Reviews 19: 559-590.
Playford, P.E. (1990). Geology of the Shark Bay area, Western Australia (pp. 13-31). In: Berry, P.F., Bradshaw, S.D. and Wilson, B.R. (eds), Research in Shark Bay, Report of the France-Australe Bicentenary Expedition Committee. Western Australian Museum, Perth, WA.

Playford, P.P. and Berry. P.F. (2002). Preliminary report on the geology of Faure Island. Unpublished field report to the Australian Wildlife Conservancy, $9 \mathrm{pp}$.

Richards, J. (2007). Return to Faure Island. Landscope 22: 10-17.

- Shack'elton, N.J. and Opdyke, N.D. (1973). Oxygen isotope and palaeomagnetic stratigraphy of Equatorial Pacific core V 28-238: oxygen isotope temperatures and ice volumes on a $10^{5}$ and $20^{6}$ year scale Quaternary Research 3: 39-55.

Slack-Smith, S.M. (1990). The bivalves of Shark Bay, Western Australia (pp. 129-157). In: Berry, P.F., Bradshaw, S.D. and Wilson, B.R. (eds), Research in Shark Bay, Report of the France-Australe Bicentenary Expedition Committee. Western Australian Museum, Perth, WA.

Walker, D. (1990). Seagrass in Shark Bay, Western Australia (pp. 101-106). In: Berry, P.F., Bradshaw, S.D. and Wilson, B.R. (eds), Research in Shark Bay, Report of the France-Australe Bicentenary Expedition Committee. Western Australian Museum, Perth, WA.

Western Australian Planning Commission (1997). Shark Bay Regional Strategy. A review of the 1988 Shark Bay Region Plan. Western Australian Planning Commission, Perth.

Wilson, B. (2008). Terrestrial gastropods of Faure Island, Shark Bay, Western Australia. Records of the Western Australian Museum Supplement 75: 21-24.

Wilson, B.R. and Allen, G. (1987). Major components and distribution of marine fauna (pp. 43-68). In: Dyne, G.R. and Walton, D.W. (eds), The Fauna of Australia, General Articles. Australian Government Publishing Service, Canberra, ACT.

Wyroll, K-H. (1993). An outline of Late Cenozoic palaeoclimate events in the Cape Range region (pp. 39-50). In: Humphreys, W.F. The Biogeography of Cape Range Western Australia. Records of the Western Australian Museum Supplement 45: 248 pp. 